\title{
Guidelines for Author
}

Artikel yang diterbitkan di Jurnal Civics: Media Kajian Kewarganegaraan adalah:

1. Artikel sesuai dengan focus and scope Jurnal Civics: Media Kajian Kewarganegaraan, belum pernah terbit dan tidak sedang proses di tempat lain.

2. Artikel tidak mengandung unsur plagiarisme lebih dari $30 \%$

3. Artikel ditulis dengan menggunakan bahasa Indonesia yang baik, gunakan alat bantu seperti grammarly (untuk bahasa inggris) dan typoonlie (untuk bahasa indonesia) agar mengurangi risiko kesalahan penulisan.

4. Artikel minimal terdiri dari 6 halaman dan tidak lebih dari 12 halaman.

5. Gunakan aplikasi seperti Mendeley, Zotero atau EndNote untuk keperluan reference management and formatting dengan style APA

6. Pastikan nama-nama yang tercantum dalam artikel benar-benar memiliki peran dalam penulisan artikel

7. Pastikan nama penulis dalam artikel dengan yang tertera dalam OJS sama (jika memiliki akun google scholar dan ORCID disarankan untuk mengisikannya pada bagian meta data penulis di OJS)

8. Untuk memudahkan dalam menyiapkan artikel, gunakan template yang telah disediakan Jurnal Civics: Media Kajian Kewarganegaraan.

a. Lakukan copy paste text only, kemudian pilih style yang telah disediakan pada bagian ribbon style

b. Simpan artikel Anda dalam format ".doc"

9. Tuliskan judul artikel Anda:

a. Tidak lebih dari 18 kata dan tidak menunjukkan dampak yang sempit

b. Hindari menggunakan kata study kasus, pengaruh

10. Penulisan afiliasi menggunakan format: Prodi, Universitas, Kota, Negara

11. Dimohon mencantumkan email seluruh penulis.

12. Abstrak tidak 150 - 200 kata, tidak mengandung unsur sitasi.

13. Sistematika sesuai dengan template yang telah digunakan Jurnal Civics: Media Kajian Kewarganegaraan.

14. Sitasi, penulis tidak dibenarkan melakukan sitasi dengan cara menyalin dari publikasi lain yang belum dibaca sumber aslinya. Misal Axxxx dalam Bxxxx

15. Referensi yang digunakan minimal 10, dengan minimal $70 \%$ dari sumber primer, sangat dianjurkan untuk menggunakan 10 tahun terakhir. 


\section{DAFTAR ISI}

Dampak sosialisasi empat pilar MPR RI terhadap Pendidikan Pancasila di perguruan tinggi

Hastangka, Armaidy Armawi, dan Kaelan $98-110$

Analisis model pembelajaran berbasis pendidikan karakter untuk membentuk karakter siswa

Dada Suhaida dan Syarifah Fadillah

Penguasaan technological pedagogical content knowledge calon guru Pendidikan Pancasila dan Kewarganegaraan

Imam Fitri Rahmadi. $122-136$

Interaksi sosial guru dalam pembelajaran Pendidikan Kewarganegaraan di SMA Katolik Karitas

Theodorus Pangalila $137-144$

Fungsi partai politik pada kekuasaan eksekutif dan legislatif berdasar pada sistem pemerintahan di Indonesia

Taufikkurrahman. $145-153$

Model desain Pendidikan Kewarganegaraan di era media digital sebagai pendukung implementasi pendidikan karakter

Anita Trisiana, Sugiaryo, dan Rispantyo $154-164$

Problematika guru dalam penerapan pendekatan saintifik pada pembelajaran PPKn Manik Nur Haq dan Mukhamad Murdiono.... $165-176$

P Relevansi konsep pemikiran pendidikan dan kebudayaan George S. Counts Dan Ki Hajar Dewantara dengan kompetensi peserta didik

Sekar Purbarini Kawuryan $177-186$

Pudarnya peran mamak Minangkabau perantauan di Kota Yogyakarta terhadap kemenakan

Setiati Widihastuti, Puji Wulandari, dan Iffah Nurhayati $187-198$

Penumbuhan kemampuan berpikir kritis PKn melalui model numbered head together Kurniasari Widiyaningrum, Edi Purwanta, dan Parsi ....

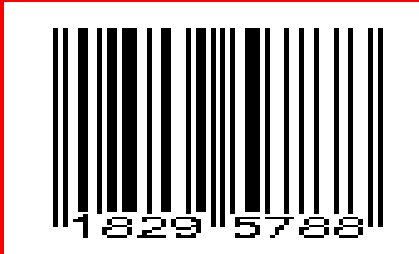

